Vol. VII, Agustus 2015

\title{
HUBUNGAN ANTARA USIA DAN PARITAS DENGAN LETAK SUNGSANG PADA IBU BERSALIN
}

\author{
(studi kasus di RSUD Dr. Soewandhi Surabaya)
}

\author{
SUMIATI, S.Kep.Ns, M.Kes \\ Prodi D-III Kebidanan Universitas PGRI Adi Buana Surabaya
}

\begin{abstract}
ABSTRAK
Letak sungsang adalah janin terletak memanjang dengan kepala di fundus uteri dan bokong di bagian bawah kavum uteri. Menurut Manuaba (2001), kejadian letak sungsang sekitar 3-4 \%, tetapi mempunyai angka morbiditas dan mortalitas janin yang tinggi. Di RSUD dr. M. Soewandhie Surabaya kejadian persalinan letak sungsang sebanyak $5 \%$. Banyak faktor yang menyebabkan meningkatnya persalinan dengan letak sungsang diantaranya oleh faktor usia ibu yang $<20$ tahun atau $>35$ tahun, dan kehamilan multiparitas pada ibu hamil dengan paritas 4 atau lebih terjadi insiden hampir sepuluh kali lipat dibanding ibu hamil nullipara, prematuritas, kelainan pada ibu atau janinnya. Penelitian ini bertujuan untuk mengetahui hubungan antara usia dan paritas dengan letak sungsang pada ibu bersalin di RSUD dr. M. Soewandhie Surabaya.

Penelitian ini menggunakan metode analitik dengan teknik Simple Random Sampling, mengambil 255 sampel dari populasi sebanyak 1400 ibu bersalin di RSUD dr. M. Soewandhie Surabaya. Analisis data menggunakan tabulasi silang dengan uji chi-square.

Berdasarkan hasil penelitian yang telah dilakukan diperoleh hasil bahwa dari 255 ibu bersalin di RSUD dr. M. Soewandhie Surabaya, adalah sebanyak 63 orang $(24,70 \%)$ mengalami letak sungsang, ibu bersalin mayoritas usia tidak beresiko (20-35 tahun), dan ibu bersalin mayoritas nonprimi (multipara atau grandemultipara).

Setelah dilakukan uji chi-square dengan $\alpha=0,05$ didapatkan Ho ditolak. Jadi dapat disimpulkan bahwa ada hubungan antara usia dan paritas dengan letak sungsang pada ibu bersalin di RSUD dr. M. Soewandhie Surabaya. Oleh karena itu, sebaiknya untuk ibu bersalin melahirkan antara usia 20-35 tahun dan paritas tidak lebih dari tiga.
\end{abstract}

Kata Kunci : Letak Sungsang, usia, paritas 
PENDAHULUAN

Persalinan adalah suatu proses fisiologis yang memungkinkan serangkaian perubahan yang besar pada ibu untuk dapat melahirkan janinnya melalui jalan lahir. Menurut Survei Sosial Ekonomi Nasional (Susenas) tahun 2008, terdapat 4,6 juta ibu bersalin, baik yang ditolong oleh tenaga kesehatan maupun yang tidak di tolong oleh tenaga kesehatan.

Angka Kematian Ibu (AKI) merupakan salah satu indikator untuk melihat derajat kesehatan perempuan. Organisasi Kesehatan Dunia (WHO) memperkirakan diseluruh dunia lebih dari 585.000 ibu meninggal tiap tahun saat hamil atau bersalin. Artinya, setiap menit ada satu perempuan yang meninggal(Prawirohardjo, 2009:7).

Di Indonesia menurut Survei Demografi Kesehatan Indonesia (SDKI) tahun 2009 Angka Kematian Ibu (AKI) masih cukup tinggi, yaitu 390 per 100.000 kelahiran hidup. Tingginya angka kematian ibu itu menempatkan Indonesia pada urutan teratas di ASEAN dalam hal tersebut. Survei Kesehatan Rumah Tangga 2001 menyebutkan angka kematian ibu di Indonesia 396 per 100.000 kelahiran hidup. Jumlah itu meningkat dibandingkan dengan hasil survei 1995, yaitu 373 per 100.000 kelahiran hidup. Departemen Kesehatan menargetkan tahun 2010 angka kematian ibu turun menjadi 125 per 100.000 kelahiran hidup. Namun target tersebut masih jauh untuk dicapai. Di mana sekitar $3-10 \%$ disebabkan oleh kasus komplikasi obstetrik, seperti kasus berat perdarahan anterpartum, perdarahan postpartum, kepala janin dan ruang panggul yang tak seimbang, malpresentasi letak janin (karena letak sungsang) serta ruptura uteri (Prawirohardjo, 2009:7)

Data di RSUD dr. M. Soewandhie Surabaya pada periode Juli s/d Desember 2010, angka kejadian letak sungsang sebanyak 76 kasus (5\%) dari 1356 ibu 
bersalin. Kejadian letak sungsang dengan usia ibu $<20$ tahun sebanyak 3 orang(4\%), usia 20-35 tahun sebanyak 61 orang $(80 \%)$, dan usia > 35 tahun sebanyak 12 orang (16\%).Sedangkan klasifikasi primipara terdapat $35 \%$ dan multipara $65 \%$. Sekitar $70 \%$ kejadian letak sungsang dilahirkan secara pervaginam dan $30 \%$ dilahirkan dengan sectio caesarea. Terdapat $6 \%$ kematian terjadi pada persalinan pervaginam.

Banyak faktor yang menyebabkan meningkatnya persalinan dengan letak sungsang diantaranya oleh faktor usia lebih dari 35 tahun berhubungan dengan mulainya terjadi regenerasi sel-sel tubuh terutama dalam hal ini adalah endometrium akibat usia biologis jaringan dan adanya penyakit yang dapat menimbulkan kelainan letak. Sedangkan hubungan letak sungsang dengan paritas karena dinding abdomen teregang secara berlebihan disebabkan olehkehamilanmultiparitas pada ibu hamil dengan paritas 4 atau lebih terjadi insidenhampir sepuluh kali lipat dibanding ibu hamil nullipara, prematuritas, penyakit sistemik, kelainan pada ibu atau janinnya. Hal tersebut jika dibiarkan begitu saja akan mengakibatkan terjadinya komplikasi baik pada ibu maupun pada janinnya (Manuaba, 1998:375).

\section{METODE}

Desain penelitian yang digunakan adalah: korelasional yaitu yang bertujuan mengungkapkan, mengkaji hubungan korelatif antar variabel. Penelitian ini dilakukan bulan April s/d Juni 2011. Populasi dalam penelitian ini adalah 1400 Ibu bersalin di RSUD dr. M. Soewandhie Surabaya periode Januari s/d Juni 2011. Sesuai dengan tujuan penelitian ini yaitu mengetahui hubungan antara usia dan paritas dengan letak sungsang pada ibu bersalin, maka data yang diperoleh dianalisa dengan menggunakan tabulasi silang dengan uji chi-square

$$
\text { ( } \chi^{2} \text { ) dengan } \alpha=0,05 \text {. }
$$


HASIL PENELITIAN

Hasil penelitian yang dapat disimpulkan adalah

Dari 255 orang ibu bersalin di RSUD dr. M. Soewandhie Surabaya, adalah sebanyak 63 orang $(24,70 \%)$ mengalami letak sungsang.

Ibu usia $<20$ tahun yang mengalami persalinan letak sungsang, yang dikarenakan usia yang muda dengan kondisi panggul sempit kemungkinan akan mengalami kesulitan dalam persalinan. Dan dapat mengancam jiwa ibu dan janin jika tidak segera mendapatkan penanganan yang tepat. Sedangkan ibu yang berusia > 35 tahun berhubungan dengan mulainya terjadi regenerasi sel-sel tubuh terutama dalam hal ini adalah endometrium akibat usia biologis jaringan dan adanya penyakit yang dapat menimbulkan kelainan letak.

Ibu bersalin di RSUD dr. $M$. Soewandhie Surabaya, mayoritas berusia tidak beresiko (20-35 th)
Hal ini sesuai dengan teori yang menjelaskan tentang hubungan paritas dengan letak sungsang yaitu di mana ibu yang telah melahirkan banyak anak sehingga rahimnya sudah sangat elastis dan membuat janin berpeluang besar untuk berputar hingga minggu ke-37 dan seterusnya yang akhirnya menimbulkan kelainan letak sungsang. Pada grandemultipara sering didapatkan perut gantung, akibat regangan uterus yang berulang-ulang karena kehamilan dan longgarnya ligamentum yang memfiksasi uterus, sehingga uterus menjadi jatuh ke depan, disebut perut gantung. Perut gantung dapat mengakibatkan terjadinya gangguan his karena posisi uterus yang menggantung ke depan sehingga bagian bawah janin tidak dapat menekan dan berhubungan langsung serta rapat dengan segmen bawah rahim. Akhirnya janin dapat mengalami kelainan letak, seperti letak sungsang (Mochtar, 1998).

Ibu bersalin di RSUD dr. M. Soewandhie Surabaya, mayoritas adalah 
nonprimi (multipara atau grandemultipara).

Akibat dinding abdomen teregang secara berlebihan disebabkan oleh kehamilan multiparitas pada ibu hamil dengan paritas 4 atau lebih terjadi insiden hampir sepuluh kali lipat dibanding ibu hamil nullipara, prematuritas, penyakit sistemik, kelainan pada ibu atau janinnya. Hal tersebut jika dibiarkan begitu saja akan mengakibatkan terjadinya komplikasi baik pada ibu maupun pada janinnya (Manuaba, 1998:375)

Ada hubungan antara usia dengan letak sungsang pada ibu bersalin di RSUD dr. M. Soewandhie Surabaya. Dari hasil uji statistik chi-square diperoleh nilai $\mathrm{x}^{2}$ hitung sebesar 8,03 dan nilai $\mathrm{x}^{2}$ tabel sebesar 3,84 yang berarti terdapat hubungan antara usia, paritas dengan letak sungsang.

\section{DAFTAR PUSTAKA}

Arifin, Z. 2009. Metodologi Penelitian Pendidikan. Surabaya: Lentera Cendekia.
Fraser, Diane M. 2009. Myles Buku

Ajar Bidan. Jakarta: EGC.

Hidayat, Azis Alimul. 2010. Metode Penelitian Kebidanan Teknik Analisis Data. Jakarta: Salemba Medika

Hutapea, Albert. 2005. Keajaibankeajaiban dalam tubuh manusia. Jakarta: Gramedia Pustaka Utama.

Manuaba, IBG. 1998. Ilmu Kebidanan, Penyakit Kandungan Dan Keluarga Berencana Untuk Pendidikan Bidan. Jakarta: EGC.

Manuaba, IBG. 2001. Kapita Selekta Penatalaksanaan Rutin Obstetri Ginekologi dan KB. Jakarta: EGC.

Manuaba, IBG. 2004. Kepaniteraan Klinik Obstetri dan Ginekologi. Jakarta: EGC.

Manuaba, IBG. 2007. Pengantar Kuliah Obstertetri. Jakarta: EGC. 
Mansjoer, Arif. 2001. Kapita

Selekta Kedokteran. Jakarta: Media

Aesculapsius.

Mochtar, Rustam. 1998. Sinopsis

Obstetri Jilid I. Jakarta: EGC.

Notoatmodjo, Soekidjo. 2010.

Metodologi Penelitian Kesehatan. Jakarta:

Rineka Cipta.

Nurani, Yuliani dkk. 2004. Seri

Mengembangkan Potensi Bawaan Anak, Persiapan dan Saat Kehamilan. Jakarta:

Elex Media Komputindo.

Nursalam. 2008. Konsep

Penerapan Metodologi Penelitian Ilmu

Keperawatan. Jakarta: Salemba Medika.

Oxorn, Harry. 2009. Ilmu

Kebidanan: Patologi \& Fisiologi

Persalinan. Yogyakarta: YEM.

Prawirohardjo, S. 2009. Ilmu

Kebidanan. Jakarta: YBPSP.
Simkin, Penny. 2008. Panduan

Lengkap Kehamilan, Melahirkan dan Bayi.

Jakarta: Arcan.

Wong, Donna L. 2008. Buku Ajar

Keperawatan Pediatrik. Jakarta: EGC.

Wiknjosastro. 2002. Ilmu

Kebidanan. Jakarta : YBPSP.

http://www.scribd.com/doc/743220

0/Letak-Sungsang, di akses 10 Maret 2011.

http://www.scribd.com/doc/128635

08/Letak-Sungsang-lengkap, di akses 10 Maret 2011.

http://nasional.vivanews.com/news

/read/105680-angka-kematian-ibu-

menurun, di akses 10 Maret 2011. 